410.

$99 \mathrm{~m}$ T c - H M- P A Oによる脳血流イメージングの基硶的及び臨床的検討

\title{
名古屋大学医学部附属病院 故射線部
}

青山裕一 ・安部哲太郎・ - 小木曾邦弘

(Yuichi Aoyana) (Tetsutaroh Abe) (Kunihiro ogiso)

野口英三 - 松浦 浩

(Eizo Noguchi)(Hiroshi Matsuura)

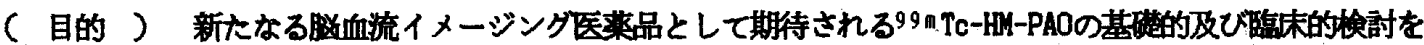
行う。

(行器） 東艺整対向角型ディジタルガンマカメラ GCA-70A 特 (現90B-E2)

(方法及ひ結果)

1) 純度試弱

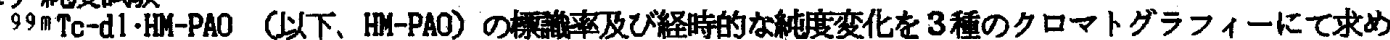

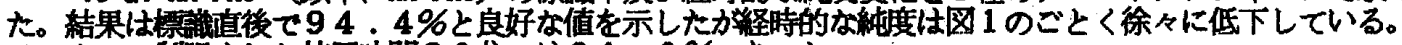
メーカーて制限された使用時間 30 分では81.0\%であった。

2) クリアランス試冾

归-PAOを患者に静拄した後、血中の放射能を測定した。血中の放射能 (図2)は初期において急速に減少 するが、徐々にゆるやかな变化となった。

3) データ収集及び処理条件

投与直後より、頭部 Dynamic Studyを行い、その後経時的に全身及び SPECT画像の収集を行った。尚、全 身画像は、対向角型ガンマカメラの長所を生かして、前後面の同時収集を行った。

4) 体内分布

1 患者の経時的体内分布を、前後 2 万向WB画像の相秉平均に上り求めた。各满器の全投与量に対する割合

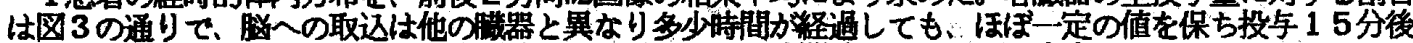
で4 .7\%であるのに対して、5時間後で4.6\%、2 4時間後で4.2\%と安定していた。Dynamic Stu dyによる、脳のTime-Activity Curve を図4に示す。約2分後より一定の值を示すことが分る。

SPECT画像より脳内の局所的な分布の变化を調べた。静柱 15 分後の值を基萑とすると、5時間以内では各 值とも約士 $10 \%$ 範囲に留まった。

5) 至暗提像時間

4)の体内分布のデータより、脳内での分布は約2分以後より安定するため、初期の時点であっても撮像 可能と考えられるが、2) の血中クリアランスのデータでは、2〜4時間程度でその変化が収まり、比較的 安定してくることから、至部撮像時間は2時間前後と推定する。

6) 他娭查法との比舫

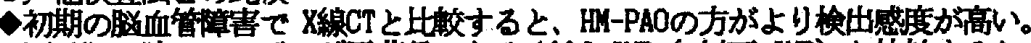

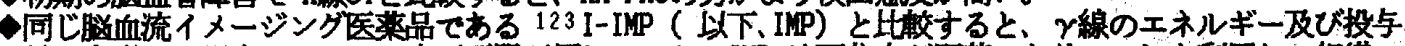

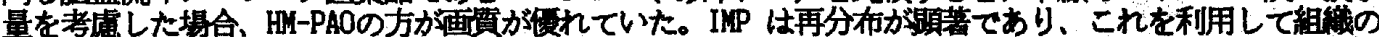
西復能を推測することも可能であるが，逆に定量性を重視すると不都合な問題となる。HM-PAOはキット化 されており、99m Tc-99Moジェネレータを角いることから安定した供給が期待できる。反面、IMP の脳への Up-take 8 . 5\%でH-PAOの Up-take住約 6\%と少し低いが、これは投与量を增やすことて対応できる。

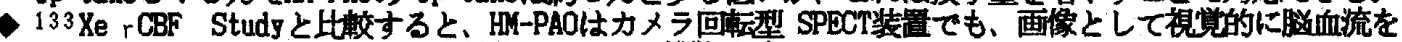
評価することができる、しかし定量化には多くの問題を含む。

( 結語 )

○HN-PAOの標融率は30分で81．0\%であった。

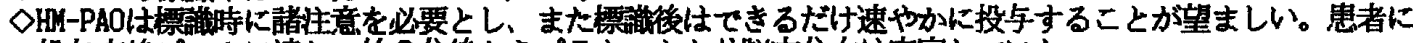
投与直後ピークに達し、約2分後からプラトーとなり这内分布は安定していた。

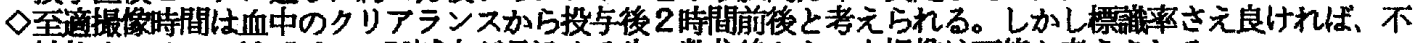
綪物やフリーの $99 \mathrm{M} \mathrm{TCO}_{4}$-のBC减少が見込める為、数分後からでも撮像は可能と考えられる。

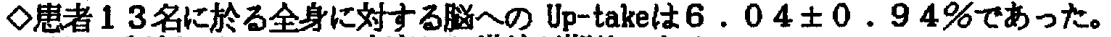

$\diamond 99$ m Tc製剂であるため、安定した供給か期待できる。

以上より、99m Tc-HM-PAOは SPECTを前提とした脳血流イメージングの医蒋品として優れていた。
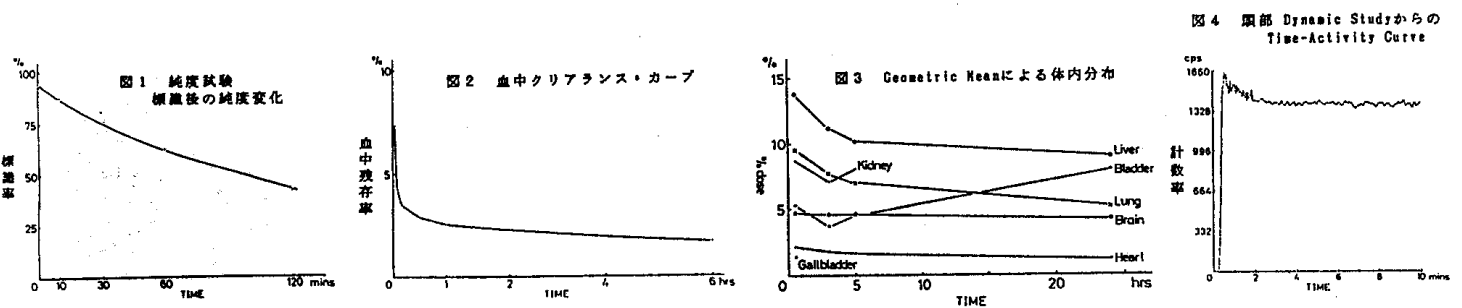